\title{
New Disease Reports \\ First report of Soybean chlorotic blotch virus and West African Asystasia virus 1 infecting cassava and a wild cassava relative in Cameroon and Togo
}

\author{
W.N. Leke ${ }^{1,2 *}$, D.B. Mignouna ${ }^{3}$, J.K. Brown ${ }^{4}$ and V.N. Fondong ${ }^{2}$ \\ ${ }^{1}$ Institute of Agricultural Research for Development (IRAD), P.O. Box 2123 Messa, Yaoundé, Cameroon; ${ }^{2}$ Department of \\ Biological Sciences, Delaware State University, 1200 N. Dupont Highway, Dover, DE 19901-2277, USA; ${ }^{3}$ International \\ Institute of Tropical Agriculture (IITA), PMB 5320, Oyo Road, Ibadan, Nigeria; ${ }^{4}$ School of Plant Sciences, The University of \\ Arizona, 1140 E. South Campus Drive, Tucson, AZ 85721, USA
}

*E-mail: walter.leke@fulbrightmail.org

Received: 28 Feb 2016. Published: 19 May 2016. Keywords: bipartite begomovirus, Geminiviridae, Manihot esculenta

Cassava mosaic disease (CMD), caused by begomoviruses (family Geminiviridae), is a major constraint to cassava (Manihot esculenta) production in Africa (Fargette et al., 1993). CMD-associated begomoviruses group either in the African cassava mosaic virus (ACMV) or East African cassava mosaic virus (EACMV) clusters (Bull et al., 2006) To determine the suspected begomoviruses associated with CMD symptoms, leaf samples were collected from five symptomatic cassava plants in Cameroon, and from three symptomatic plants in Togo in August 2014 (Table 1). Total DNA was isolated as described by Shepherd et al. (2008). Circular, single-stranded DNA was enriched by rolling circle amplification (RCA). The RCA products were pooled by country of origin and sequenced using the Illumina HiSeq 2500 next-generation sequencing (NGS) platform. Sequence reads were assembled into full-length vira sequences $($ c. $2.7 \mathrm{~kb}$ ) using SeqManNGen software v.3 (DNASTAR Inc., Madison, WI) and subjected to BLASTn analysis. In addition to the ACMV DNA-A and B components as expected, the DNA-A and B components of Soybean chlorotic blotch virus (SbCBV) (Olufemi et al., 2010) and West African Asystasia virus 1 (WAAV1) (Wyant et al., 2015) were also identified. For SbCBV, sequence identities ranged from $97-99 \%$ and 95-96\% for the DNA-A and B components, respectively, whereas for WAAV1, sequence identities ranged from $92-95 \%$ and $93-96 \%$ for the DNA-A and B components, respectively. The sequences have been deposited in the GenBank as the DNA-A components SbCBV-CM-Cas (Accession No. KT444613), SbCBV-TG-Cas (KT454813), WAAV1-CMCas (KT444603), and WAAV1-CM-wildcas (KT444605), and as the DNAB components SbCBV-CM-Cas (KT444614) SbCBV-TG-Cas (KT454814), WAAV1-CM-Cas (KT4446040, and WAAV1-CM-Cas (KT444606).

To confirm the presence of SbCBV and WAAV1 in the cassava samples, PCR was carried out using specific primers designed to the $C P$ and $B V I$ gene, located on the DNA-A and B components of SbCBV and WAAV1, respectively. The DNA sequence for each cloned amplicon was determined by Sanger sequencing. Amongst the five samples collected from Cameroon, three were infected only with ACMV, one was infected with ACMV and WAAV1, and one was infected with ACMV, SbCBV and WAAV1. The three Togolese samples were all infected with ACMV and one was also infected with SbCMV. BLASTn analysis of the $C P$ and $B V 1$ genes indicated that they shared $99-100 \%$ sequence identity with the NGSdetermined sequences. To our knowledge, this is the first report that cassava may be infected by SbCBV or WAAV1 in Africa. The isolates shared a close phylogenetic relatedness with previously described SbCBV and WAAV1 isolates, respectively (Fig. 1). This indicated that cassavaassociated isolates are strains or isolates of SbCBV and WAAV1 based on the guidelines of the ICTV Geminiviridae Study Group for strain and species demarcation (Brown et al., 2015). The grouping of EACMV, SbCBV, WAAV1, and Madagascar Asystasia virus (MAAV) together in a separate clade (Fig. 1), suggests that they have probably evolved from a common ancestor, despite perhaps recent adaptation to host plants representing different plant families. Whether symptoms caused by SbCBV and WAAV1 are masked by the presence of ACMV in cassava remains to be determined. Giving the small number of samples analysed, further work is required to understand the contribution of these two viruses in cassava mosaic disease epidemiology in Africa.

\section{Acknowledgements}

This research was partly funded by National Science Foundation award number IOS-1212576. Walter Leke was supported by the Fulbright Foundation.

\section{References}

Brown JK, Zerbini FM, Navas-Castillo J, Moriones E, Ramos-Sobrinho R, Silva JCF, Briddon RW, Hernandez-Zepeda C, Idris AM, Malathi VG, Martin DP, Rivera-Bustamante R, Ueda S, Varsani A, 2015. Revision of Begomovirus taxonomy based on pairwise sequence comparisons. Archives of Virology 160, 1593-1619. http://dx.doi.org/10.1007/s00705-015-2398-y Bull SE, Briddon RW, Sserubombwe WS, Ngugi K, Markham PG, Stanley J, 2006. Genetic diversity and phylogeography of cassava mosaic viruses in Kenya. Journal of General Virology 87, 3053-3065.

http://dx.doi.org/10.1099/vir.0.82013-0

Fargette D, Jeger M, Fauquet CM, Fishpool LDC, 1993. Analysis of temporal disease progress of African cassava mosaic virus. Phytopathology 84, 91-98. http://dx.doi.org/10.1094/Phyto-84-91

Olufemi JA, Kumar PL, Mgbechi-Ezeri JU, Naidu RA, 2010. Two new 'legumoviruses' (genus Begomovirus) naturally infecting soybean in Nigeria. Archives of Virology 155, 643-656.

http://dx.doi.org/10.1007/s00705-010-0630-3

Shepherd DN, Martin DP, Lefeuvre P, Monjane AL, Owor BE, Rybicki EP, Varsani A, 2008. A protocol for the rapid isolation of full geminivirus genomes from dried plant tissue. Journal of Virology Methods 149, 97-102. http://dx.doi.org/10.1016/j.jviromet.2007.12.014

Wyant P, Strohmeier S, Fischer A, Schäfer B, Briddon RW, Krenz B, Jeske $\mathrm{H}, 2015$. Light-dependent segregation of begomoviruses in Asystasia gangetica leaves. Virus Research 195, 225-235.

http://dx.doi.org/10.1016/j.virusres.2014.10.024
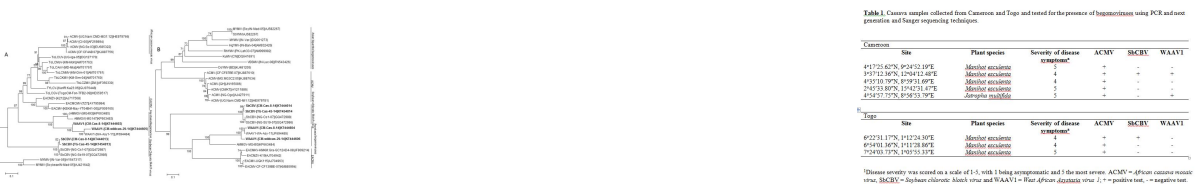

To cite this report: Leke WN, Mignouna DB, Brown JK, Fondong VN, 2016. First report of Soybean chlorotic blotch virus and West African Asystasia virus 1 infecting cassava and a wild cassava relative in Cameroon and Togo. New Disease Reports 33, 24. http://dx.doi.org/10.5197/j.2044-0588.2016.033.024 